\title{
The Influence of Discipline, Ability, and Incentive to Motivation and Performance of Employee in Pt. IndosatOoredoo, Tbk Bandar Lampung
}

\author{
M.Renandi Ekatama ${ }^{1}$, Andi Surya ${ }^{2}$, Pudji Astuty ${ }^{3}$, Maria Septjanti Alie ${ }^{4}$ \\ \{renandi@umitra.ac.id ${ }^{1}$, andisangsurya@umitra.ac.id², pudji_astuty@borobudur.ac.id ${ }^{3}$, \\ mariaalie@umitra.ac.id $\left.{ }^{4}\right\}$ \\ Lecturer of Businnes Faculty of Universitas Mitra Indonesia, Lampung Indonesia ${ }^{1,2,3}$ \\ Lecturer of Economic Faculty of Universitas Borobudur, Jakarta Indonesia ${ }^{4}$
}

\begin{abstract}
This research aims to know the influence of discipline, ability, and incentive to motivation and performances of employee, as well as to know the influence of motivation to the employee performance in PT Indosatooredoo, Tbk Bandar Lampung. This research used saturated sample, involving all employees in PT Indosatooredoo, Tbk Bandar Lampung, which consists of 32 samples. The analysis method used in this research is path analysis. The result shows that discipline, ability, and incentive simultaneously have positive and significant influence to employee performance. Discipline has positive and significant influence to employee performance, incentive has positive and significant influence to employee performance and motivation as the media of the influence of discipline, ability, and incentive to the employee performance. Based on the result of the research, PT Indosatoredo, Tbk Bandar Lampung should civilize discipline, give ability improvement chance and fair incentive awarding, as well as motivate the employee by offering job promotion.
\end{abstract}

Keywords: Discipline; Ability; Incentive; Motivation and Employee Performance

\section{Introduction}

It is expected by every company that they achieve high productivity as well as achieve maximum profit in minimum cost. Arranged program and fully available facilities will be useless without reliable workforce. PT Indosatooredoo, Tbk. Bandar Lampung is international telecommunication provider Service Company in Indonesia. Established as the first foreign investor in 1967 in Indonesia which offering International telecommunication service, PT. Indosatooredoo Tbk, Bandar Lampung has 32 employees. This company really needs a reliable and competent human resource to support working implementation. Employee performance is the key to success in achieving the company's vision and mission, in which to be the network providers and develop innovative and have high quality service and social products, to give the best benefits to customers. Factors affecting employee performance are discipline, ability, incentive and motivation. 
Work discipline is an employee driving tool, it must be applied in the company because by disciplining the employee, it will improve their performance. However, if the discipline is not enforcedor applied by all employees, then the employees' performance will decrease. Ability is employees' potency to do tasks or work in the company. Adequate employee performance will have an impact on good company results as well. Incentives are either compensation or rewards paid to employees and have no relation with wages and salaries, on the basis of producing products that exceed certain targets. Incentives are necessary to improve employee performance and income.

Motivation is a booster for someone to do its activities with a motive to have a certain goal achieved. It is expected that employee performance will improve from the high motivation, no motivation in the company will lead to a decrease in employee performance, considering that factors in assessing employee performance at PT. Indosatooredoo Tbk, Bandar Lampung is very important. Based on the explanation above, the authors are interested to conduct research with the title: "Factors Affecting Motivation and Its Impact on Employee Performance At PT. Indosatooredoo Tbk, Bandar Lampung".

\subsection{Problem Identification}

Based on the background of the study, it can be identified some problem as follow:

a. How big is the influence of the variable of work discipline, ability, and incentive partially to themotivation variable?

b. How big is the influence of the variable of work discipline, ability, and incentive simultaneouslyto the motivation variable?

c. How big is the influence of the variable of work discipline, ability, incentive, and motivationpartially to the variable of employee performance?

d. How big is the influence of the variable of work discipline, ability, incentive, and motivationsimultaneously to the variable of employee performance?

\subsection{Research Objective}

The objectives in this research are:

a. To know how big is the influence of the variables of work discipline, ability, and incentivepartially to the variable of working motivation.

b. To know how big is the influence of the variables of work discipline, ability, and incentivesimultaneously to the variable of work motivation.

c. To know how big is the influence of variables of work discipline, ability, incentive, andmotivation partially to variable performance of employees.

d. To know how big is the influence of variables of work discipline, ability, incentive, andmotivation simultaneously to employee performance variable.

\subsection{Uses of Research}

From the results of the study, it is expected to provide benefits as follows:

a. Theoretical Uses

1. To add and enrich knowledge about human resources related to motivation, discipline,environment, work effectiveness and productivity.

2. The results of this study are expected to be useful as a scientific material that can be useful forthe one who need. 
b. Practical Uses

1. For authors, it is as media to apply statistics learned in college and to know the actual conditions of motivation, discipline, environment, effectiveness, and work productivity.

2. For the company, it can give thought contribution for company leader in taking wisdom inorder to increase motivation, discipline, environment, effectiveness, and work productivity.

\section{Theoretical Framework}

\subsection{Work Discipline}

According to Singodimejo in Sutrisno, (2014: 86) the discipline of work is an attitude of willingness of a person to obey the regulation of norms applied [1]. With a good work discipline, it will accelerate the company's goals, whereas with the declining work discipline, it will be a barrier and hamper to achieve company goals. Factors affecting the discipline of work are the frequency of attendance, the level of alertness, adherence to standards of work, adherence to rules and work ethics. The purpose of work discipline is to motivate employee, maintain a mutual respect relationship, increase work performance and discipline.

\subsection{Ability}

According to Robbins in (Wibowo, 2015: 93) Ability shows individual certainty to realize various tasks in the work [2]. It is an assessment of what a person can do right now. The individual ability is basically formed by 2 groups of factors: Intellectual and Physical Abilities. Ability or competence is a basic characteristic that associated with the effectiveness of individual performance in the work or the basic characteristics as a reference of effective or superior performance at work in certain situations [3]. Robbins in (Wibowo, 2015: 102) stated that the whole ability of an individual basically consists of 2 groups of factors, which are the knowledge and physical ability [2].

\subsection{Incentive}

Incentives are either compensation or rewards given to employees and have no relation to wages and salaries, on the basis of producing products that exceed certain targets. If the incentives received are not on the basis of exceeding the target set, but on the basis of the individual then the worker is not increasing in achievement, otherwise it will make the worker lazier. Like bad attendance, decreasing in employee productivity and performance. According to Hasibuan (2013: 118) incentive is additional remuneration given to employee whose achievement is above the standard [4]. This incentive is a tool used in supporting fair compensation. According to Handoko (2002: 56) in (Wibowo, 2015: 89) there are six factors that affect incentives, they are [2]: Performance, Duration of work, Seniority, Needs, Justice and Proper, and Job Evaluation.

\subsection{Motivation}

According to Sutrisno (2014: 109), motivation is a factor that encourages a person to 
performa certain activity, therefore motivation is often defined as a factor that encourages the behavior of someone [1]. Every activity done by someone must have a factor that encourages them to do these activities. In achieving certain target, employees usually have factors that encourage them. Someone'sneeds or desires will not be the same as one another. These desire and needs vary due to the mental and the characteristics process that occur in an employee. Factors that affect motivation are: internal factorsand external factors.

\subsection{Employee Performance}

According to Mangkunegara (2013: 67), the term of performance is derived from the Job Performance and Actual Performance (achievement or actual achievement that can be achieved by someone) [5]. Then the definition of performance is the actual work result for the quantity achieved by an employee in performing their duties in accordance with the responsibility given. Wibowo (2015: 7) stated that performance is the result of work or work achievement, but actually it has a broad meaning not only as the work result, but also how the work process takes place [2]. Performance assessment is a systematic evaluation of the work that has been performed by the employees and objected for development. Work performance assessment in global competition demanding high performance from each employee [6].

\section{Conceptual Framework}

This research was conducted to examine the influence of work discipline, ability, and incentive variable on motivation and performance. The research was conducted at PT. Indosatooredoo Tbk, Bandar Lampung, the factors that are suspected in affecting employee performance include work discipline, ability, incentive, and motivation. Improving work discipline, ability, intensive awarding, and growing employee motivation can provide benefits to both company and national.

The results of this research has a positive influence that by creating and improving employee good work discipline is an important part of organizational management to maintain profitable conditions for the company. This research refers to Nurcahyo (2011) that work discipline has a positive effect on employee performance, this means that improving and maintaining the discipline of employee can increase employee performance in company [7]

.In this research, the ability is also one of the factors that affect the employee motivation and performance. Ability is the potential owned by employees to perform tasks or work in the company. Sachroni (2013) in his research concluded that factors of motivation, ability, role perception and situational organization affect employee performance.[8] This is in line with research done by Anton (2011) which shows that the results of ability hypothesis testing have a positive influence on employee performance.

While for the incentive variable, this research refers to a research by Suprihati (2014) which concluded that motivation, incentive and work environment significantly affect employee performance [9]. According Hasibuan (2013:118) incentive is additional remuneration given to employee whose achievement is above standard. This incentive is a supporting tool used in giving compensation [4]. According to Pengabean in Mulyadi, (2015: 82 ) incentive is compensation that bind salaries with productivity, incentive is rewards in the form of money based on their heads that can work through established standards [6]. The main objective in providing incentive is to give full responsibility toemployee and motivate them to increase productivity and lead to organizational goals, so that the company will be able to 
increase profits and can maintain the life sustainability of the company.

In this research, motivation also affects employee performance, this refers to research by Suprihati (2014) which concludes that motivation, incentive and work environment significantly affect employee performance.[9] Motivation is a factor that encourages a person to perform a certain activity, therefore motivation is often defined as a factor that encourages the behavior of someone. Every activity done by someone must have a factor that encourages them to do these activities [1]. According to Mulyadi (2015: 93), the purpose of providing employee a work motivation are to improve employee morale and job satisfaction, to improve employee productivity, to maintain employee stability in company, to improve discipline in employee, make the employee procurement effective, to create a good atmosphere and good working relationships, to increase loyalty, creativity and participation of the employee, to increase employee prosperity level, to enhance employee sense of responsibility for their duties, and to improve the efficiency in using materials [6].

In addition to work motivation, implementation of employee performance is conceptually defined as the result of work in quantity, quality and punctuality achieved by an employee in doing their duties based on the responsibility given to them. Based on the explanation above, it can be drawn a conceptual framework in this research as can be seen in Figure 1:

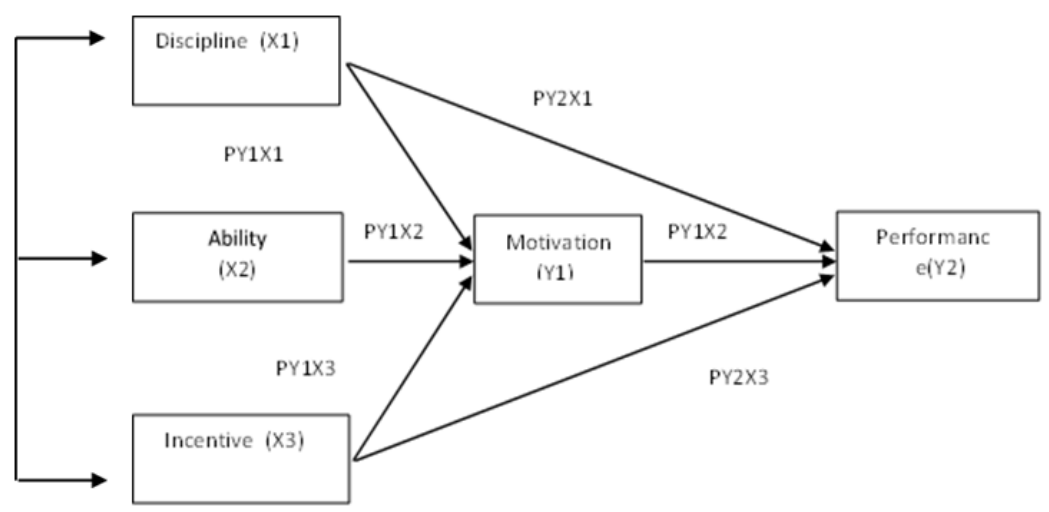

Fig. 1. Conceptual Framework

\subsection{Hypotheses}

Based on hypothetical model of research that has been made, then the hypothesis proposed in thisresearch are:

Hypothesis 1 : Variable of work discipline, ability, and incentive partially to motivation variable.

Hypothesis 2 : Variable of work discipline, ability, and incentive partially to motivation variable.

Hypothesis 3: Variable of work discipline, ability, and incentive partially to variable of employeeperformance.

Hypothesis 4 : Variable of work discipline, ability, and incentive simultaneously to variable ofemployee performance. 


\section{Methodology}

\subsection{Research Design}

Research design used in this research is survey research method with quantitative approach. The independent variables used are variables of work discipline (X1), ability (X2), incentive (X3), and motivation (Y1) as intervening variable. While the dependent variable used is the variable of Employee Performance (Y2). To know the relationship and influence between independent variable and dependent variable, it is used path analysis [10].

\subsection{Location and Time of Research}

The location of research was conducted at PT. Indosat Ooredoo Tbk, branch Lampung in Bandar Lampung, while the time of research was conducted in March to July 2020.

\subsection{Population and Research Sample}

Population in this research is all employees at PT. Indosatooredoo Tbk branch Lampung in Bandar Lampung which are 32 employees both male and female. Sampling used is saturated sampling technique where all population is taken entirely to be sample (Sugiyono, 2015: 60), so the number of samples in this study is 32 people.

\subsection{Data Collecting Technique}

Data collecting techniques are important step in the research, because without using the right technique, then the researcher will not get the data according to the standard set. In this research, the data collecting techniques used are literature study and interview by using questionnaires that have been prepared previously.

\subsection{Operational Variables Definition}

The operational variables definition which will be studied is a way to make it easier in measuring the research variables. It also gives clear boundaries on the object studied.

\subsection{Work Discipline (X1)}

Work discipline is the implementation of management to strengthen organizational guidelines. In an organization, a leader needs tool to communicate with employees about the behavior of employees, and how to improve their behavior to be better, and work discipline applied by the leader's communication tool [5]. The concept of work discipline in this study is measured by indicators of integrity, obeying organizational rules, obeying working time and time management.

\subsection{Ability (X2)}

Ability or competence is a basic characteristic of a person related to the effectiveness of the individual's performance in their work or the basic characteristics that are used as an effective benchmark or prime or superior performance in the workplace in certain situations 
[3]. The concept of work ability in this research is measured by indicators of intellectual ability and physical ability.

\subsection{Incentives $(\mathrm{X} 3)$}

According Hasibuan (2013: 118) incentive is additional remuneration given to employee whose achievement is above standard. This incentive is a tool used to support the principle of outcome in the compensation awarding. According to Mulyadi, (2015: 82), incentive is compensation that binds salary with productivity, incentive is reward in the form of money based on their individual who can work through established standards [6]. The concept of incentives in this research is measured by indicators of performance, duration of work, seniority, needs, fairness and eligibility, and job evaluation.

\subsection{Motivation (Y1)}

According to Sutrisno (2014: 109), motivation is a factor that encourages a person to performa certain activity, therefore motivation is often defined as a factor that encourages the behavior of someone. Every activity done by someone must have a factor that encourages them to do these activities. In addition, according to Hasibuan in Sutrisno (2014: 110), motivation is a stimulus of the desire and the driving force of the work of a person. Every motive has a certain goal to be achieved [1]. The concept of motivation in this research is measured by indicators of internal motivation and external motivation.

\subsection{Employee Performance (Y2)}

According to Moeheriono (2012: 69), the meaning of the word performance derived from the word job performance and also called the actual performance or work achievement that has been achieved by employee [3]. Performance is a description of the level of achievement in an implementation of a policy program in realizing the goals, objectives, vision and mission of the organization as outlined through the planning of an organizational strategy. Wibowo (2011: 7) stated that performance is as a result of work or work achievement. However, it actually has a broad meaning not just as result of work, but includes how the work process takes place. Motivation concept in this research ismeasured by some indicators as quantity of job, job quality, punctuality, attendance, cooperation.

\section{Data Analysis}

The method of analysis used to test the hypothesis in this study is using path analysis technique that is standardized and calculated through the SPSS program. So path analysis model is used to analyze the relationship pattern between variables with the aim to know the direct or indirect effect of independent variables to dependent variables. According to Sugiono (2013: 130) other benefits in using path analysis model are [10]: (1) Explanation to the phenomena or problems studied; (2) Predicted value of dependent variable (Y) based on free variable value (X), and prediction with path analysis is qualitative; (3) Determinant factor is the determination of the independent variable $(\mathrm{X})$ which has dominant influence on the dependent variable (Y), can also be used to trace (paths) the influence of independent variable (X) on the dependent variable (Y); (4) Testing the model, using the theory of trimming, either 
for the reliability test in existing concepts or in testing the development of new concepts. Furthermore Sugiono (2013: 128) describes the underlying assumptions of path analysis, which are:[10] (1) In the path analysis model, the relationship between variables is linear adaptiveand normal; (2) Only a causal flow system in one direction, which means no inverted causal direction; (3) Minimum dependent variable in the interval and ratio scale; (4) Using probability sampling whichis a sampling technique to give equal opportunity to each member of the population to be elected as a sample member; (5) Observed variables are measured without error (valid and reliable measurement instruments) which means that the observed variables can be observed directly; (6) The analyzed model is specified (identified) based on relevant theories and concepts that the model of the theory studied or tested is built on a particular theoretical framework that is able to explain the causal relationship between the variables studied. The path coefficient is calculated by two structural equations, which is the regression equation that shows the hypothesized relationship. In this case these two structural equations are:

$\mathrm{Y} 1=P_{Y 1} \mathrm{X} 1+P_{Y 1} \mathrm{X} 2+P_{Y 1} \mathrm{X} 3+\varepsilon \mathrm{i}$

$\mathrm{Y} 1=$ Motivation

$\mathrm{X} 1=$ Work DisciplineX2 $=$ Ability

$\mathrm{X} 3=$ Incentive

$\mathrm{P}=$ Coefficient Path $\varepsilon=$ Error

$\mathrm{Y} 2=P_{Y 2} \mathrm{X} 1+P_{Y 2} \mathrm{X} 2+P_{Y 2} \mathrm{Y} 1+\varepsilon \mathrm{i}$

Y2 = Employee PerformanceX1 = Work Discipline

$\mathrm{X} 2=$ Incentive $\mathrm{Y} 1=$ Motivation

$\mathrm{P}=$ Coefficient Path $\varepsilon=$ Error

\section{Result and Discussion}

\subsection{Respondent's Characteristics}

The number of respondents involved in this research is 32 respondents from employees at PT. Indosatooredo, Tbk, branch Bandar Lampung. Characteristics of respondents in this research consist of age, gender, recent education and work experience. The characteristics description of the following respondents already describes the existing population because the entire population is taken to be sample. While the diversity of respondent characteristics can play a role in differentiating the assessment of the four variables studied. The number of respondents aged less than 30 years old is 18 respondents $(56.25 \%)$ while the rest as many as 14 respondents $(43.75 \%)$ is aged more than 30 years old. The number of respondents by gender is 23 males $(71.87 \%)$, the rest 9 is female $(28.13 \%)$. Employee education level is dominated by bachelor degree with total of 21 respondents $(65,63 \%)$ and the rest 11 respondents $(34,47 \%)$ are high school graduated.

Characteristics of respondents based on work experience shows that respondents have experience of working over five years is 17 respondents $(53.23 \%)$, while the remaining 15 respondents $(47.67 \%)$ have work experience less than five years. Work operational in the telecommunication service company's environment includes program formulation, job targets 
and job evaluation, so that in this context required the ability of employees to work individually or team. In line with the developments experienced by the information and telecommunication industries, the need for high- competence workers have also grown rapidly in line with the growth and development of the telecommunications and information industries.

\subsection{Path Analysis Results}

The estimation of all path coefficients for the variables included in this research model can be seen in Table 1 below:

\begin{tabular}{cccc} 
Table 1. Results of Path Coefficient Test & \\
\hline $\begin{array}{c}\text { Independent } \\
\text { Variables }\end{array}$ & $\begin{array}{c}\text { Dependent } \\
\text { Variables }\end{array}$ & $\begin{array}{c}\text { Regression } \\
\text { Coefficient }\end{array}$ & Significance \\
\hline Work Discipline & Motivation & 0,494 & 0,004 \\
Ability & Motivation & 0,375 & 0,039 \\
Incentive & Motivation & 0,135 & 0,048 \\
Work Discipline & Employee Performance & 0,197 & 0,024 \\
Incentive & Employee Performance & 0,485 & 0,000 \\
Motivation & Employee Performance & 0,175 & 0,026 \\
\hline
\end{tabular}

Source: Primary Data Processed, 2020.

Table 1 above explains that the six paths in the hypothetical model are not all pathways significant. The dominant role of work motivation comes from the discipline of work. Meanwhile for the employee performance, dominant influence comes from the Incentive. In particular, these two dominant paths become interesting because it becomes the determinant of high employee performance. For more details of the whole path analysis results, it can be presented in Figure 2.

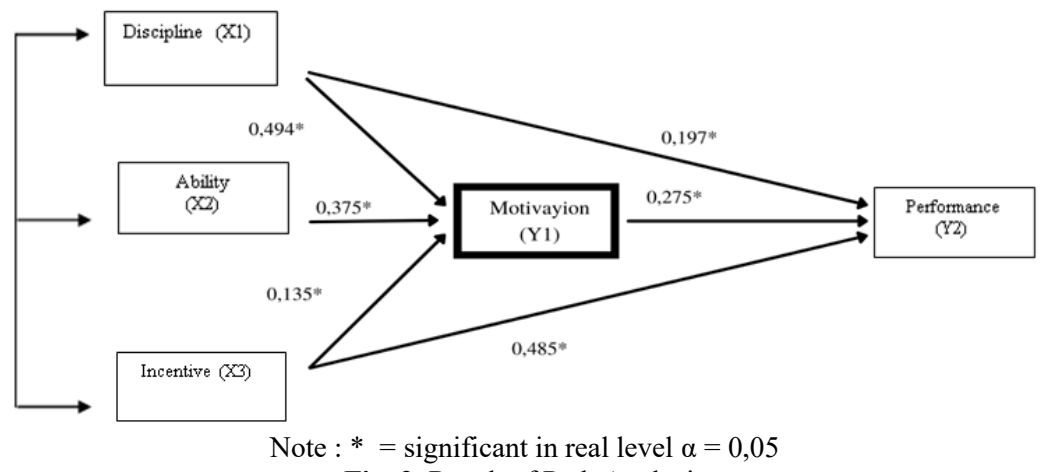

Fig. 2. Result of Path Analysis

\subsection{Model Accuracy}

The accuracy of the hypothetical model of the research data is measured from the relationship of two determination coefficient (R2) in both equations. In the first equation, it is get R21 which is 0,662 and R22 which is 0,848 in second equation. 
The result of model accuracy is:

$\mathrm{R} 2$ model $=1-(1-\mathrm{R} 21)(1-\mathrm{R} 22)$

$=1-(1-0,662)(1-0,848)$

$=1-(0,338)(0,152)$

$=1-0,152$

$=0,848$ or $84,8 \%$

The calculation result of model accuracy which is $86,2 \%$ explained that the contribution of model to explain the structural relationship of the five variables studied is $84.8 \%$ and the rest of $15.2 \%$ is explained by other variables which is not included in the model.

\subsection{Effect of Work Discipline on Work Motivation}

There is hypothesis which stated that the discipline of work directly affects the employee motivation significantly. This is shown by the regression test results where the probability (p) is less than 0.05 which means significant. This means that the discipline of work has a real effect on employee work motivation. The amount of path coefficient (PY1X1) which is 0.494 indicates the effect of work discipline for employees of PT. Indosatooredo, Tbk Bandar Lampung to work motivation is positive. This means that all efforts to cultivate the discipline of work to employees who get a positive response will be a factor in increasing the high employee work motivation. Every employee in carrying out their work should be able to build a sense of responsibility with the activities taken. Work discipline for employee is very important to motivate them in performing their duties. The impact of work discipline on employee motivation will increasingly improve the performance of employee in the company.

\subsection{Effect of Work Discipline on Employee Performance}

Hypothesis which stated that work discipline directly affected employee performance is proven. This can be shown from regression test where the probability (p) is less than $\alpha=0,05$ which means significant. This means the work discipline has direct influence on employee performance. The amount of path coefficient (PY2X1) is 0,234 and significantly shows that employee performance can be explained directly by work discipline. The high employee performance appears as the result of work discipline implemented or cultivated by the employee. The result of the path analysis explained that the employee performance is greatly affected by the work discipline applied by employee. This result is in line with research by Sidanti (2015) and Hidayat and Taufiq (2012) which concluded that there is a significant effect between the work discipline and employee performance [11];[12].

\subsection{Effect of Ability on Work Motivation}

Hypothesis which stated that the variable of ability has an effect on the real variable of work motivation is proven. This is shown by regression test results where the probability (p) is less than $\alpha=0.05$ which means significant. This means ability has positive influence on variable of employee motivation. The amount of path coefficient (PY1X2) is 0.375, it indicates the effect of employeeability variable of PT. Indosatooredo, Tbk Bandar Lampung on work motivation is positive. This means that the ability of employee is very important to grow and spur work motivation that in the endit can improve employee performance results in the company. 


\subsection{Effect of Incentives on Work Motivation}

The hypothesis that stated the incentive variable has direct effect on employee motivation is proven. This can be seen from the regression test where the probability (p) is less than $\alpha=$ 0,05 which means significant. This means that the incentive provided by the company has a significant effect on employee motivation. The amount of path coefficients (PY1X3) which is 0.135 and significant indicates that employee motivation can be explained directly by the incentive variable. This result is in line with research done by Ulfa, et al (2013) which concluded that there is a significant effect between incentive and employee motivation [13]. High employee motivation arises as a result of providing incentiveby the company as a reward for achievement shown by the employee.

\subsection{Effect of Incentives on Employee Performance}

Hypothesis testing that stated incentives directly affect employee performance is proven. This can be seen from the regression test where the probability (p) is less than $\alpha=0.05$ which means significant. It means that incentive has a direct significant effect on employee performance. The amount of path coefficient (PY2X3) is 0.485 and significant. This shows that employee performance can be explained directly by intensive variables. High employee performance arises as a result of intensive given by the company to employee. The result of path analysis explains that employee performance is highly influenced by incentive variable applied by company. This result is in line with a research by Fauziah (2012) and Martcahyo (2012) which concluded that there is a significant effect between incentive variables on employee performance [14];[15].

In principle, incentive is reward given to an employee who performs a job outside his or her principal duties or exceeds the target of the job to which they are assigned [16] Jackson et al (2011: 192) said that incentive payments are a one-time payment for each award. Incentive payments provide an opportunity to earn a substantial amount of performance-based wages [17]. Rewarding incentive is intended to provide different wages / salaries because it is a different work achievement [18].

\subsection{Effect of Motivation on Employee Performance}

Hypothesis testing which stated that the motivation directly affects the performance of employee is proven. This can be seen from the regression test where the probability (p) is less than $\alpha=0.05$ which means significant. This means that the variable of motivation has a direct significant effect on employee performance. The amount of path coefficient (PY1Y2) is 0,175 and significant. This shows that employee performance can be explained directly by motivation variable. High employee performance arises as a result of employee motivation in working. The results of the path analysis explained that the employee performance is greatly affected by the motivation variables owned by the employee. These results are in line with a research done by Hidayat and Taufiq (2012) and Sajangbati (2013) which concluded that there is a significant effect between the variables of motivation on employee performance [12];[19].

Someone with low motivation tend to show feelings of discomfort and displeasure with their work. So the greater the motivation of the individual as an employee can improve the performance of the employees themselves. Lack of work motivation from the leader to employee in company will hamper the performance of employee and also create an unfocused working atmosphere. Here the occurrence of unfocused motivation to employees by leaders 
means lack of motivation given by leaders which sometimes is not in accordance with their work performance, where the one who have high-motivation tend to have high work performance and vice versa, those whose performance is low is possibly because the low motivation. Motivation can encourage employee to work diligently, as well as discipline in work so that it can achieve company goals in creating conducive atmosphere in the work environment in company. Not all employee wants to mobilize their ability optimally, so it is still needed the encouragement from outsiders, for that reason in order to grow the motivation of work inan organization required an intensive communication between employee with leader or among other employee.

\section{Conclusion and Suggestion}

Based on the result of the research, it can be concluded that work discipline has positive and significant effect to work motivation in PT Indosatooredoo, Tbk Bandar Lampung. This means the more discipline the employee then the motivation of employee of PT. Indosatoredo, Tbk Bandar Lampung will increase. While the variable of employee ability also has a positive influence on work motivation, so that to maintain the increase in employee motivation, PT. Indosatoredo, Tbk Bandar Lampung must be programmed and well planned to improve the ability of its employees.Discipline has a positive and significant effect on the employee performance of PT. Indosatoredo, Tbk Bandar Lampung. This means that high discipline will improve employee performance. Ability has a positive and significant effect on the work motivation of PT. Indosatoredo, Tbk Bandar Lampung.

This means, the higher the ability of employee will encourage employee motivation to increase in working. Incentive has a positive and significant impact on employee motivation in PT. Indosatoredo, Tbk Bandar Lampung. This means that incentive given fairly to employee will be able to increase employee work motivation. Incentive has a positive and significant effect on the employee performance of PT. Indosatoredo, Tbk Bandar Lampung. This means more frequent incentive given as rewards from work achievement will encourage and improve employee performance in the company. Motivation has a positive and significant influence on the employee performance of PT. Indosatoredo, Tbk Bandar Lampung. This means that the more motivated employee will create a good relationship among employees of PT. Indosatoredo, Tbk Bandar Lampung which will increase. Based on these conclusions, the suggestion that can be taken is the company should apply the discipline of work, improve the ability of employee as well as give rewards as an incentive so that it can encourage employee work motivation and at the same time will improve their work performance in company.

Company should continuously keep maintaining and fostering planned motivation to the employee so that they are always motivated and keep working better in the company, so that in the end, employee performance can always be improved and maintained properly. This research is expected to be a reference for PT. Indosatooredoo, Tbk Bandar Lampung in order to improve employee performance for the sustainability of the company itself. For further researcher, it is expected to be able to develop this research model by adding other variables that affect employee performance besides discipline, ability, incentive, and motivation supported by the latest theories and issues. The next researcher is also expected to expand the scope of the research area and the location ofthe research so that the results of the research can be implemented in general. 


\section{References}

[1] Sutrisno, Edy. (Eds). Manajemen Sumber Daya Manusai. Jakarta: Kencana Prenada Media Grup (2014)

[2] Wibowo. Dr. (Eds). Prilaku dalam Organisasi. Jakarta: PT. Raja Grafindo Persada (2015).

[3] Moeheriono. Dr. (Eds). Pengukuran Kinerja Berbasis Kompetensi. Jakarta: Rajawali Pers (2012).

[4] Hasibuan. Malayu S.P (Eds). Manajemen Sumber Daya Manusia. Jakarta: PT. Bumi Aksara, (2013)

[5] Mangkunegara, Anwar Prabu. Manajemen Sumber Daya Manusia. PT. RemajaPasda Karya, Bandung (2013)

[6] Mulyadi. Manajemen Sumber Daya Manusia (MSDM). Penerbit IN MEDIA, Bogor (2015)

[7] Nurcahyo, Anyon. Analisis Variabel-Variabel Yang Mmempengaruhi Kinerja Karyawan Pada PT. Quadra Mitra Perkasa Balikpapan. Jurnal Eksis, Volo.7(2), 18162000 (2011)

[8] Syachroni.2013. Analisis Faktor-Faktor Yang Mempengaruhi Kinerja Karyawan Guru SMA Negri 4 Kota Jambi. Jurnal Dinamika Manajemen .Vol.1(2),121-138

[9] Suprihati.2014. Analisis Faktor-Faktor Yang Mempengaruhi Kinerja Karyawan Perusahaan Sari Jati di Sragen. Jurnal Paradigma. Vol. 12(01),93-119

[10] Sugiyono. 2013. Metode Penelitian Bisnis. Bandung: Alfabeta.

[11] Sidanti, Heny. Pengaruh Lingkungan Kerja, Disiplin Kerja, dan Motivasi Kerja Terhadap Kinerja Pegawai Negri Sipil Di Sekretariat DPRD Kabupaten Madiun. Madiun, (2015). Available on: http://lp3m.asia.ac.id/wp-content/uploads/2012/10/7JURNAL-HENY-S-MADIUN-JIBEKA-VOL-9-NO-1-FEB-2015.pdf

[12] Hidaya, Zainul dan Taufiq, Muchamad. 2012. Pengaruh Lingkungan Kerja dan Disiplin Kerja serta Motivasi Kerja Terhadap Kinerja Karyawan Perusahaan Daerah Air Minum (PDAM) Kabupaten Lumajang. http://ejournal.Stiewidyagamalumajang.ac.id/index.php/wiga/article/view/64/73

[13] Ulfa, M, Ruhana, KR. 2013. Pengaruh Kompensasi Terhadap Motivasi Kerja Dan Kinerja Karyawan (Studi pada Karyawan Auto 2000 Malang Sutoyo) http://administrasibisnis.studentjournal.ub.ac.id/index.php/jab/article/viewfile $/ 123 / 211$

[14] Fauziah, H. 2012. Pengaruh Insentif dan Motivasi Kerja Terhadap Kinierja Pegawai Pada Kantor Dinas Bina Marga Balai Besar Pelaksanaan Jalan Nasional III Satker Pelaksanaan Jalan Nasional Wilayah Bandar Lampung. https://s3.amazonaws.com/academia.edu. documents/37149987/7-hujaimatulfauziah.pdf?AWSAccessKeyId=AKIAIWOWYYGZ2Y53UL3A\&Expires=152941805 2\&Signature $=\% 2 \mathrm{BO} \% 2 \mathrm{BjnzcrXKgJ6A} \% 2 \mathrm{FkfSSpH} 3 v y m 0 \% 3 \mathrm{D} \&$ response-contentdisposition=inline $\% 3 \mathrm{~B} \% 20$ filename $\% 3$ Dhujaimatul_Fauziah _Pengaruh_ insentif_ dan.pdf

[15] Martcahyo, VA, Hidaya, W, dan Suryoko, S. 2013.Pengaruh Pelatihan Kerja, Jaminan Sosial, danIntensif Terhadap Kinerja Karyawan Bagian Produksi PT. FUMIRA Semarang. [Online] Available on: https://scholar.google.co.id/scholar? start $=90 \& q=$ pengaruh + insentif + terhadap + motiv as $i+$ karyawan $\& h l=i d \&$ ass $d t=0,5$

[16] Bachrun, Saifuddin. (2011). Menghitung Tunjangan, Insentif, Bonus dan Fasilitas 
dalam Praktik.Jakarta : Penerbit PPM.

[17] Jackson, Schuler, Werner. Pengelolaan Sumber Daya Manusia (10th ed.). Salemba Empat, Jakarta (2011)

[18] Ardana, Komang, Ni Wayan Mujiati, I Wayan Mudiartha Utama. 2012.Manajemen Sumber DayaManusia. Yogyakarta : Graha Ilmu

[19] Sajangbati, Ivonne AS. 2013. Motivasi, Disiplin, dan Kepuasan Pengaruhnya Terhadap Kinerja Pegawai PT. POS INDONESIA (PERSERO) Cabang Bitung.https://ejournal.unsrat.ac.id/index.php/emba/article/viewFile/2750/2303 